\title{
Air inflated Greenhouse As Urban Farming Facilities: Architectural Overview
}

\author{
Syed Zainol Abidin ${ }^{1}$, Ronny D. Nasihien ${ }^{2}$, Hery Budiyanto ${ }^{3}$ \\ UTM Johorbahru Malaysia \\ Narotama University, \\ Universitas Merdeka Malang
}

budiyantohery@yahoo.com

Received : Juli 3, $2017 \quad$ Accepted : $\quad$ September 5, 2017

\begin{abstract}
Urban Farming utilizing land intensification, in order to meet the needs of fresh vegetables and fruits every day for the community residential / housing in urban areas. Air Inflated Greenhouse as urban farming facilities, can be built and transferred to a residential location / specific housing is easy, safe, fast and lightweight $(0,55 \mathrm{~mm}$ PVC tarpaulin) so that urban farming products closer to consumers in urban settlements, the price impact getting cheaper, but quality. Long -term goal is to develop prototype Air inflated Greenhouse as facilities Urban Farming which fulfills the power, speed, effectiveness, comfort and encourage crops of fruit / vegetable hydroponic hygienic, cheap and profitable, so that the product Air Inflated Greenhouse automatically support an increase in food production, specific target is the availability prototype Air Inflated Greenhouse as Urban Farming facility in order to increase productivity of crops of fruit / vegetable hydroponic hygienic, cheap and profitable, so the high prospects for mass production by SMEs Partners to meet national food requirements. Methods using methods Experiments and Action Research, beginning with the development of design, manufacture, testing and repair of prototype Air Inflated Greenhouse includes (1) a test of strength and endurance of materials Air Inflated Greenhouse to the weather, (2) test material Air Inflated Greenhouse most effective as a component of the structure, (3) test the speed of manufacture, transport, assembly, installation, dismantling Air Inflated Greenhouse, (4) test the temperature, humidity and air pressure in the Air Inflated Greenhouse.
\end{abstract}

(C) 2017 Published By IJTI. This is an Open Acces article under the CC BY SA License https://creativecommons.org/licenses/by-sa/4.0/

Keyword : Urban Farming, Air Inflated Greenhouse, Terpaulin

\section{INTRODUCTION}

FAO (Food and Agriculture Organization) describes the Urban Farming as an industry that manufacture, process, and market agricultural products, especially meet the daily demand of consumers in urban areas, with intensive production methods, utilize and recycle resources and urban waste to produce a variety of plant food needs of urban communities (Smit, J et al, 1996). Council on Agriculture, Science and Technology (CAST) said Urban Agriculture includes aspects of environmental health, remediation, and recreation (Butler, L et al, 2002). In many cities, the Urban Farming supporting aspects of the beauty of the city and the feasibility of the use of spatial sustainable. Urban farming is also carried out to increase revenue or activity produce food for family consumption, and in some places is done for the purpose of recreation and relaxation (Fraser et al, 2002). In the USA the agricultural town has a role in poverty reduction, food insecurity and address the garbage problem. Agriculture cities can guarantee the availability of fresh and nutritious food, so meningkan intake of vegetables and fruit and can save 15-30 percent of the budget on food (kabarkampus.com). The potential of urban farming in 
Indonesia is very large, from 10.3 million ha yard area that has not been used more than $30 \%$ are in urban areas. Besides the consumption of vegetables and fruit Indonesian community of only $40 \mathrm{~kg} /$ capita / year, while the Food and Agriculture Organization of the United Nations (FAO) requires ideally vegetable consumption of $73 \mathrm{~kg} /$ capita / year (industri.bisnis.com). Urban agriculture provide optimal results with the facilities and technology Greenhouse Hydroponics. Greenhouse increase the intensity of crop protection from rain, sunlight and microclimate, as well as optimizing plant maintenance, fertilization and micro irrigation, so as to increase the production of vegetables, fruits and flowers quality irrespective of the season (G. Thiyagarajan et al, 2007). Greenhouse easier with Air Inflated Structure technology that can meet the requirements of strength, comfort and speed in space in the greenhouse construction. Structure Air inflated membrane material can be resistant to weather up to more than 10 years, depending on the type of material (Setiawan, M. Ikhsan, 2014). Besides Air Inflated Structure Materials proved to be reliable based on lab testing Narotama and Field Test, give satisfactory results include strong tensile test up to $218.3 \mathrm{~kg}$, material durability $>70^{\circ} \mathrm{C}, 3$ minute installation and 3 minute dismantling and temperatures in room $<35^{\circ} \mathrm{C}$ (Setiawan, M. Ikhsan et al, 2015). Air Inflated Structure can be used in a confined area, lightweight structural materials (PVC $0.55 \mathrm{~mm}$ terpaulin), easily removed, folded and transported to another location just by truck / pickup. This paper seeks to explore the Air Inflated Greenhouse as Urban Farming Support the National Food Security. Urgency is as follows: (1) Potential Urban Farming in Indonesia is very large, from 10.3 million hectares of yard area that has not been used more than $30 \%$ are in urban areas. Besides fruit and vegetable consumption of Indonesian is still low at only $40 \mathrm{~kg} /$ capita / year, while the Food and Agriculture Organization of the United Nations (FAO) requires ideally vegetable consumption of $73 \mathrm{~kg} /$ capita / year (industri.bisnis.com); (2) Urban Farming provide optimal results with the facilities and technology Greenhouse Hydroponics. Greenhouse technology increases the intensity of crop protection from rain, sunlight and microclimate, as well as optimizing plant maintenance, fertilization and micro irrigation, so as to increase the production of vegetables, fruits and flowers quality irrespective of the season (G. Thiyagarajan et al, 2007); (3) Research shows that if urban farming is applied to the housing / settlement in Surabaya, may attract buying interest of consumers, potential consumers are young families upper middle class housing, and urban farming is the predominant desired fruit plants (Ghana, AyuKemala, 2014); (4) Greenhouse technology more easily supported the implementation of Air Inflated Technology that can meet the requirements of strength, speed, comfort in the room and the feasibility of growing plants fruit / vegetable hidoponik therein; (5) Air Inflated Greenhouse into solutions of food availability in urban hygiene, cheap and profitable, due Greenhouse flexible placement in residential / housing with hydroponic technology that is commonly applied to urban agriculture community; (6) Air Inflated Greenhouse has high prospects for mass produced by SMEs Partner, due to high demand for urban food and inadequate availability of hygienic food production, but cheap price.

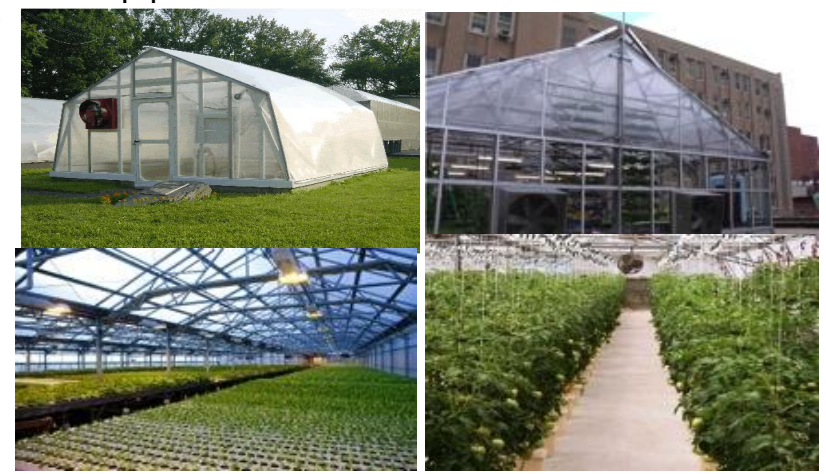

Figure 1. Greenhouse and supporting tools Source: greenestcity.ca 
URBAN FARMING

MATERI AL AND METHOD

Green property currently has a tendency to appeal to consumers. Developers are challenged to provide a real unique selling point in the product properties to attract customers in this green trend. Agriculture cities (urban farming) has the potential not only green but also productive. With the concept of urban farming, not only benefit consumers but also residential green integrated with refreshing means in the form of farm tours. Opportunity is a business that can serve as a diversified developer of the concept of green property residential property amid the competition. While the potential for developers in Surabaya is no housing that carries the concept of urban farming (Ghana, AyuKemala, 2014). Additionally Agriculture Urban led the community as "foodies", "Locavores", "organic growers" that serves as a means of sharing information and facilities and selling local product, thereby generating income, reducing the risk of pesticides and chemicals excess in consumption, thereby increasing resilience food, b ecause the closer the distance between producers and consumers so that preservatives and no additional processing is needed. This makes consumers get a guarantee of foodstuffs obtained so fresh (Thornton, A, 2011). Studies show that by moving from food that was grown locally could save emissions from the transportation of foodstuffs as much as 50,000 metric tons of carbon dioxide, which is equivalent to removing 16.191 cars from the road. As the impact of reduced energy usage, carbon footprint of a city as a result of the Urban Agriculture business also reduced. (Xuereb, M, 2005), (Delta Institute, 2013).According to Penney and Prior (2014) In Wales and Scotland, it was found that local food is more popular; with 45 and 41 per cent of consumers', respectively, purchasing local food. These findings also showed that local food is purchased more frequently in London. This can be accredited to the aspirational nature of the product, with London consumers wishing to lead a rural life and they appear to be buying into that way of life when purchasing local food (IGD, 2006). Improved taste, freshness and quality of produce are cited as key drivers for consumers when purchasing local food (Seyfang, 2006; Chambers et al., 2007; Murphy, 2011). IGD (2008) found that these factors were the main reasons for consumers purchasing local food, with 60 per cent of consumers stating "freshness" as their top motivational factor. In agreement with this view, Tippins et al. (2002) states that consumers believe that local produce will be "fresher" due to a shorter distribution channel which allows for fruit and vegetables to ripen more naturally. While factors such as freshness and taste are functional drivers for the purchase of local food, consumers are also motivated by emotional factors such as supporting the local economy, supporting local jobs and small scale producers (Adsearch, 2009; Groves, 2005). The Food Standards Agency (2007) found this was one of the top two reasons for purchasing local food; supporting local business (57 per cent) and supporting local area and community (51 per cent). In support of this, the IGD (2008) found that 44 per cent of respondents cited support for local producers as their reason for buying. Thus, consumers view local food as a driver of the local economic climate and are keen to support it for these reasons. Seyfang $(2006, p$. 7$)$ found that a third of consumers saw local food as a way of "preserving local heritage and tradition". Consumers are therefore looking to form a relationship with producers and farmers, and "make the link between the foods they buy and the production origins and methods underlying them" (Weatherall et al., 2003). For instance, both Murphy (2011) and Tippins et al. (2002) found that consumers enjoy farmers' markets due to the enabling of consumer interpersonal engagement with stallholders within the marketplace. This claim is also highlighted by Hinrichs (2000) who researched the USA where farmers' markets have rapidly grown since the 1970s. The findings reveal that for farme rs' markets within New York State, visitors enjoyed the market experience as a social event. Weatherall et al. (2003) found that knowledge of food provision was greater for rural consumers and they were more able to make links between food and farming. Subsequently, this may encourage rural

\section{Air inflated Greenhouse As Urban Farming Facilities: Architectural Overview} Syed Zainol Abidin, Ronny D. Nasihien, Hery Budiyanto 
consumers to be more responsive to local food, in contrast to the urban consumer. The Netherlands has one of the most advanced hydroponic technology implementation as the largest producer of hydroponic products in the world. The total land area of hydroponic cultivation reached 10,000 ha. Hydroponics products in the Netherlands accounted for $50 \%$ of the value of all fruit and vegetables produced in the country. The main commodity namely peppers, tomatoes, and cucumbers and cut flowers, especially roses, gerbera, carnation and chrysanthemum. Mostly destined for export markets. Almost all production activities in the greenhouse using hydroponic techniques with NFT system and rockwool culture. NFT is a method of cultivating plants with the roots of plants growing in shallow layers and nutrients to circulate. Plants grown in a layer of polyethylene with plant roots submerged in water containing nutrient solution is circulated continuously with a pump. Thus the plants can get enough water, nutrients and oxygen. While Rockwool or commonly known as Mineral Wool is also a hydroponic techniques are made by heating the mineral rocks in a very high temperature that it becomes fibers. The fibers are then incorporated into a kind of loom and then into a form that is similar to foam (trubus-online.co.id).

\section{AIR INFLATED STRUCTURE}

Pneumatic structure is a system of building structure tent constructed from thin sheets of flexible material, stabilized by the pressure difference with the medium: gas liquid, foam, or fine grain materials. When the flexible membrane composition given medium that causes a pressure difference, it forms a pneumatic ("pneuma" which means bubbles filled with air). Inflated membrane able to withstand the forces of the outside, because it turns into a pressure medium and medium holder into element thus forming a pneumatic load-bearing structure (Hery, 1992; Herzog, 1976). Building a tent with a material that weighs no more than $3 \mathrm{~kg} / \mathrm{m} 2$ is able to shade the soil with a span of more than 100 meters (Otto, 1973) despite using pressure difference is not too great between the inner and outer space (Luchsinger, at.al., 2004), How to work with a tent pole structure inflated with air is as follows: Air pressure is used to inflate the forms (eg: arc, beams, columns) that is used to support the building cover (Schodek, 1980). The air pressure inside and outside of the building is the same (Figure 2).
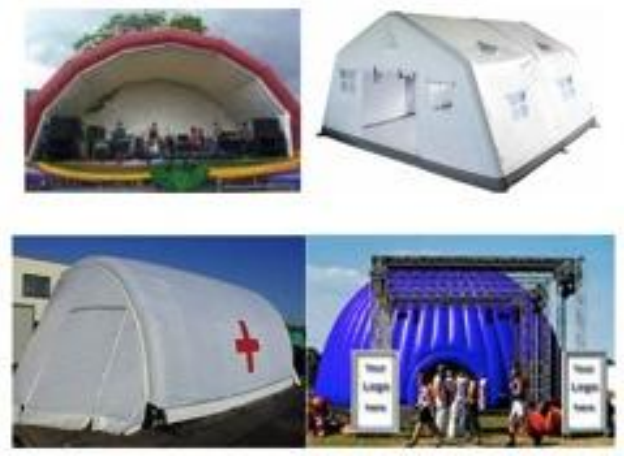

Figure 1. Various Functions Tent With Frame Structure which Inflated Air (Air inflated Structure)

Source: images.google.co.id.

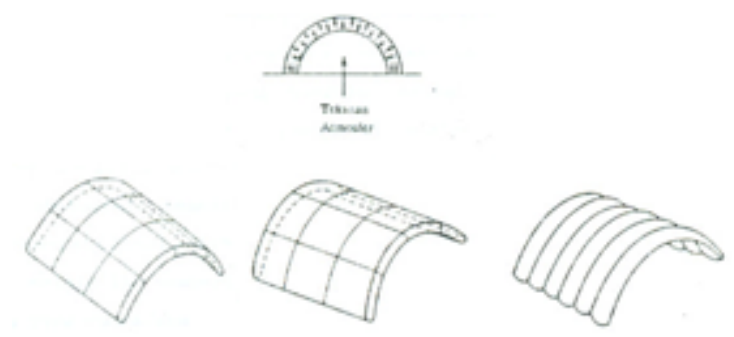

Air inflated Greenhouse As Urban Farming Facilities: Architectural Overview Syed Zainol Abidin, Ronny D. Nasihien, Hery Budiyanto 


\section{Figure 2. Basic Principles of Frame Structure which Inflated Air (Air inflated Structure) Source: Daniel Schodek, 1980}

Thomas Herzog (1976) classify material pneumatic membrane structure into two, namely: isotopic material (strength and strain on the whole the same direction) and an-isotropic material (its depending on the direction). Isotropic materials include: plastic films, fabrics, rubber membrane, a metal foil. Tetoron polyester fabric such as a pneumatic membrane structures can be weather resistant up to more than 10 years, depending on the type of material coatingnya

\section{Table 1: Resistance polye ster fabric belapis} Source: Thoma s Herzog, 1976

\begin{tabular}{|l|c|}
\hline \multicolumn{1}{|c|}{ Bahan pelapis } & Ketahanan \\
\hline PVC bening & $3-8$ tahun \\
\hline PVC bening ditambah 2-6\% $\mathrm{TiO}_{2}$ & $8-12$ tahun \\
\hline PVC warna opaque & $10-18$ tahun \\
\hline chloroprene & $8-12$ tahun \\
\hline polyethilene chlorosulfat & $12-20$ tahun \\
\hline polyurethane & $4-6$ tahun \\
\hline
\end{tabular}

Testing security against fire, among others, performed by The Swedish Research Laboratory. Tests conducted for the membrane material of polyester fabric coated with PVC concluded that the fire hazard is very low throughout the building tent is not used to store flammable items; Protection against fire in buildings pneumatic tent is the same as the equipment used for ordinary buildings. Activities such as smoking and weld allowed throughout always pay attention to the safety factor. (Schulz, 1967). The construction process of Air In flated Structure is through three phases, namely fabrication, transportation and construction. In modern countries (Europe and USA) are Air Inflated Structure is not a new thing, the third process is done by different parties. The construction process which has a skeleton structure tent Air Inflated Structure becomes the object of research. Research and testing of the system structure of pneumatic, among others, in a test model of the structure of the pneumatic in 1992 has been carried out in the paper "Study and Design Building Structures Pneumatic who emphasized the aspect Techniques and Methods Construction, Case Study: Roof Structure Single Pneumatic Membrane support by the Air in the Gymnasium"(Budiyanto, Hery, 1992). The experimental model of the structure is necessary to know the behavior of the prototypestructure on a smaller scale. One of the recommendations of the study is a pneumatic structure has several advantages compared with the conventional structure, the initial investment is low, the speed and ease of development, easy maintenance, structural elements can be folded (compact) that can be stored in a warehouse with a size of $3 \times 3 \mathrm{~m}^{2}$, resulted in a prototype pneumatic structure support by the Air (Budiyanto, Hery, 2010). This prototype can be built in just 30 minutes, the building area of $150 \mathrm{~m}^{2}$ is ready to accommodate 50 people. The downside of this prototype is the use of rigid doors should be airtight so difficult for ordinary people to familiarize thems elves out of the tent bubbles. Purwanto as outlined in the article entitled "The Development of Structures Pneumatic Enriching Architectural Design" (Purwanto, 2000) convey the possibility of applying and developing the structure of the pneumatic in Indonesia, among others climatic conditions in Indonesia, especially the problem of wind, not a significant problem and can be reckoned with calculation pressure in the pneumatic structure. Things that need to be considered in the use of pneumatic structure in Indonesia, among other behavioral, social conditions of the people of Indonesia need to be improved, especially in the maintenance of the building. Fad aspect of society in view and treat the building / public facilities often cause damage. However, people need to be familiarized with the system and introduced a new structure this so that they can learn on one condition, shape, behavior or a new civilization. Alain Chassagnoux and his colleagues in the "Teaching of Morphology" (Chassagnoux et.al., 2002) explains that in order to study the forms of contemporary architecture that uses nonconventional structure. The lecturers can ask students to conduct experiments model so get the 
"form" of the building using elements / components designed by the students. With the study of the shape of the building through the study of geometry and science will provide the experience formation of structures is difficult and hiperhitungkan mathematically. Greenhouse technology is getting easier with Air inflated Structure technology that can meet the requirements of strength, comfort in the room and speed in the Greenhouse construction. Structure Air inflated membrane material can be resistant to weather up to more than 10 years, depending on the type of material coatingnya (Setiawan, M. Ikhsanet.al, 2014). Besides Air inflated membrane Materials Structure proved to be reliable based on lab testing Narotama and Field Test, give satisfactory results include strong tensile test up to $218.3 \mathrm{~kg}$, material durability $>70^{\circ} \mathrm{C}, 3$ minute installation and 3 minute dismantling and temperatures in room $<35^{\circ} \mathrm{C}$ (Setiawan, M. Ikhsan et.al, 2015 (a)). Structure inflated water can be used in a confined area, lightweight structural materials (PVC $0.55 \mathrm{~mm}$ terpaulin), easily removed, folded and transported to another location just by truck / pickup (Setiawan, M. Ikhsanet.al, 2015 (b))

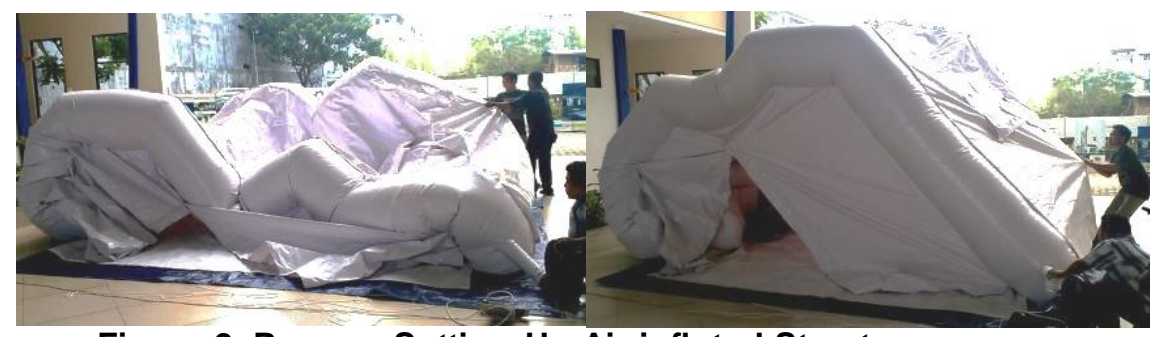

Figure 2. Process Setting-Up Air inflated Structure

(Source: Setiawan, M. Ikhsanet.al, 2015 (a))

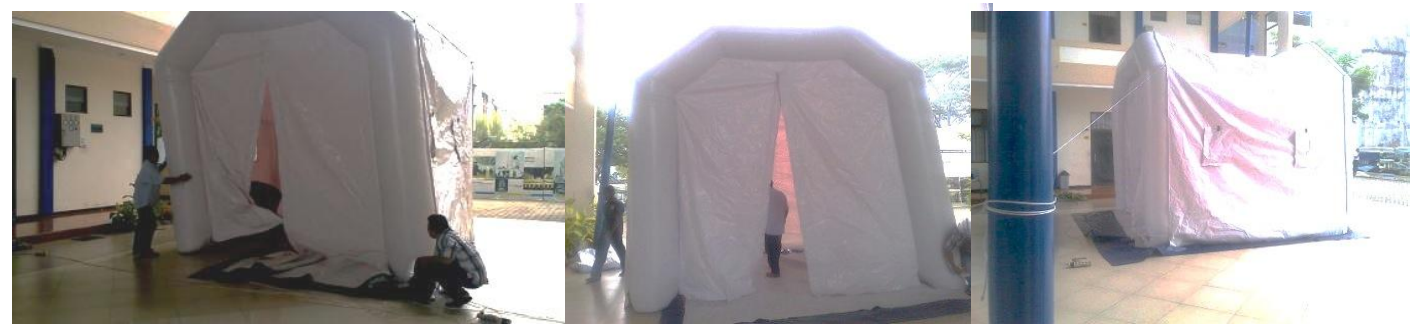

Figure 3. Finishing Process Air inflated Structure

(Source: Setiawan, M. Ikhsan et.al, 2015 (a))

\section{RESULT AND DISCUSSION}

This research uses experimental methods and action research in the form of prototyping, testing laboratory and testing field for a wide range of variables (Cowan, 1968), such as testing of material Air Inflated Greenhouse. According to Penney and Prior (2014) future research needs to further examine how the growth of local food and the urban consumer can develop in the future.

\section{CONCLUSIONS AND SUGGESTION}

In particular, the urban consumer's relationship with supermarkets needs to be further explored. Also, it is necessary to explore the attitudes of urban consumers from other urban areas. Supermarkets market local food needs more attention in order to fully gain an appreciation of the ways in which the purchase of local food for urban consumers can be increased. Future research could explore the factors of influence within the attitude-behaviour gap which would offer more insights into potential barriers of local food and how these could be mitigated to encourage the purchase of local food for urban 
consumers.

\section{REFERENCES}

[1] Budiyanto, Hery (1992) Kajian dan Perancangan Bangunan dengan Konsep Struktur Pneumatik yang Ditekankan pada Aspek Teknik dan Metoda Konstruksi, Kasus Studi: Struktur Atap Pneumatik Membran Tunggal yang Ditumpu Udara pada Gedung Olah Raga, Tesis S2, InstitutTeknologi Bandung

[2] Budiyanto, Hery (2007) Uji coba Model Dan Prototipe Tenda Pneumatik Sistem Knock Down Sebagai Bangunan Penampungan Sementara Untuk Korban Bencana, Laporan Penelitian Hibah Kompetisi A2, Teknik Arsitektur Universitas Merdeka Malang

[3] Budiyanto, Hery (2010) Pembuatan Tenda Pneumatik Sistem Knock Down Yang Ringkas Dan Cepat Bangun Sebagai Bangunan Penampungan Sementara Untuk Korban Bencana, Laporan Penelitian Hibah Bersaing Tahun 2008-2010, Teknik Arsitektur Universitas Merdeka Malang

[4] Butler, L, Moronek, D.M (2002) Urban and Agriculture Communities: Opportunities for Common Ground, Ames, lowa: Council for Agricultural Science and Technology

[5] Chassagnoux, Alain, et.al (2002) Teaching of Morphology, International Journal of Space Structures, Vol.17 No. 2 \& 3, Multi Science Publishing Ltd., Brendwood (UK) Delta Institute, Urban Agriculture

[6] Dent, Roger N (1971) Principles of Pneumatic Architecture. London: Elsevier Publishing Company

[7] Fraser, Evan, D.G (2002) Urban Ecology in Bangkok Thailand: Community Participation, Urban Agriculture and Forestry, Environments 30 (1).

[8] G. Thiyagarajan, R. Umadevi\& K. Ramesh (2007) Hydroponics, Science Tech Entrepreneur-Water Technology Centre-Tamil Nadu Agricultural University, India

[9] Ghana, AyuKemala (2014) Peranan Urban Farming dalam menarik minat beli konsumen pada Real Estate Perumahan di Surabaya, Tesis, S2 Arsitektur -Perancangan Real Estate, ITS, Surabaya

[10] Herzog, Thomas (1976) Pneumatic Structures, a handbook for the architect and engineer. London: Cros by Lockwood Staples

[11] Intent (2005) Membran Structures. Kortrijk: Intent Inc

[12] Itek (2005) Air Cell Technology. Pennsylvania: Inflatable Technology -USA Inc

[13] Luchsinger, Rolf H. et.al. (2004) Pressure Indicated Stability: From Pneumatic Structure to Tensairity. Article No.JBE-2004-025, Journal of Bionic Engineering. Vol.1. No.3, hal.141148, Jilin University - Nanling Campus, Changchun PR China

[14] Otto, Frei (1973) Tensile Structures. Cambridge: The MIT Press

[15] Penney, Ursula and Prior, Caroline (2014) Exploring the urban consumer's perception of local food, International Journal of Retail \& Distribution Management, Vol. 42 No. 7, 2014, pp. 580-594, Emerald Group Publishing Limited

[16] Purwanto (2000) Perkembangan Struktur Pneumatik Memperkaya DesainArsitektur. Jurnal DimensiVol 28 No. 1, Universitas Kristen Petra, Surabaya

[17] Salvadori, Mario (1981) Structural Design in Architecture. New Jersey: Prentice Hall Inc

[18] Schodek, Daniel (1980) Structures. New Jersey: Prentice Hall. Inc

[19] Schueller, Wolfgang (1983) Horizontal Span Building Structures. New York : John Wiley \& Sons

[20] Setiawan, M. Ikhsan, Budiyanto, Hery (2014) The Development of Air Inflated Structure as the Facility on Natural Disaster Area, Australian Journal of Basic and Applied Sciences, ISSN 1991-8178, April Issue 2014

[21] Setiawan, M. Ikhsan, Budiyanto, Hery, et.al (2015) Pengembangan Bangunan Air Inflated Structure sebagai fasilitas Tanggap Bencana, Seminar NasionalTeknologi (SENATEK) 
2015, ITN Malang

[22] Setiawan, M. Ikhsan, Budiyanto, Hery, et.al (2015) Poros Maritim Dunia dan Bencana Tsunami :Pengembangan Air Inflated Structure sebagaifasilitas TanggapBencana, Seminar NasionalTeknikSipil XI-2015, ITS Surabaya

[23] Smit, J., A. Ratta, J. Nasr (1996) Urban Agriculture: Food, Jobs, and Sustainable Cities. United Nations Development Programme (UNDP), New York, NY.

[24] Sukawi (2011) Struktur Membran dalam Bangunan Bentang Lebar, Jurnal Modul Vol.11 No.1. ISSN:0853-2877, Universitas Diponegoro, Semarang

[25] Thornton, A (2011) Food for thought? The potential of urban agriculture in local food production for food security in the South Pacific. In Campbell, H. Rosin, C. and Stock, P. (eds) Dimensions of the Global Food Crisis. London: Earthscan. Pg 200-218.

[26] www.industri.bisnis.com

[27] www.kabarkampus.com 28. www.trubus-online.co.id

[28] Xuereb, Marc (2005) Food Miles: Environmental Implications of Food Imports to Waterloo Region. Public Health Planner Region of Waterloo Public Health

[29] Zuhri, Syaifudin (2010) Dasar-dasarTektonik: Arsitektur dan Struktur. Klaten: Yayasan Humaniora 